\title{
PATHOPHYSIOLOGICAL CHANGES IN LIVER TISSUES OF HYPERCALORIE DIET-INDUCED OBESE RATS
}

\begin{abstract}
BHARATHA AMBADASU ${ }^{1 *}$, RAMADEVI $S^{2}$, NAIKAWADI AA ${ }^{1}$, NAVEEN KUMAR M $^{3}$
${ }^{1}$ Department of Pharmacology, Shri BM Patil Medical College Hospital and Research Center, Vijayapur, Karnataka, India. ${ }^{2}$ Department of Pathology, Santhiram Medical College and General Hospital, Nandyal, Andhra Pradesh, India. ${ }^{3}$ Department of Oral Pathology, Sree Sai Dental College and Research Institute, Srikakulam, Andhra Pradesh, India. Email: ambu2mail@gmail.com
\end{abstract}

Received: 27 September 2016, Revised and Accepted: 07 October 2016

ABSTRACT

Objectives: Hypercalorie diet intake has been associated with many long-term complications including metabolic syndrome, cardiovascular diseases, and nonalcoholic fatty liver disease.

Methods: A total of 12 Wistar rats either sex were used in this study. These animals were randomly divided into two groups as control and obese rats. Group 1 consists of six rats weighing 150-200 g and fed with normal pellet chow. Another six rats were fed hypercalorie/cafeteria diet to induce obesity and included in the study after 19 weeks of age. All animals were sacrificed; liver tissues were collected, weighed and sent for the histopathological examination.

Results: Weight of liver tissues of was significantly more in obese rats than the control rats. Histopathological examination shows an excessive fat deposition and sinusoidal congestion in the liver tissues of obese rats.

Conclusion: Increase in body weight is associated with the increase in fat deposition in the liver tissues which further develops into inflammation and necrosis of liver cells.

Keywords: Wistar rats, Hypercalorie/cafeteria diet, Obese rats, Histopathological examination.

(C) 2017 The Authors. Published by Innovare Academic Sciences Pvt Ltd. This is an open access article under the CC BY license (http://creativecommons. org/licenses/by/4. 0/) DOI: http://dx.doi.org/10.22159/ajpcr.2017.v10i1.15422

\section{INTRODUCTION}

Altered eating habits together with decreased physical activity distorts the usual balance of nutrient intake and energy expenditure and lead a net accumulation of nutrients. This positive nutrient balance directs metabolic control mechanisms in various tissues to an anabolic set favoring nutrient storage. Excess carbohydrate, protein, or lipid is stored in the form of triglyceride in adipose tissue, which can expand or contract with the tides of energy flow. Relative or absolute nutritional overload, nutrient interconversion to fat and the subsequent storage of fat in adipose tissue are invariably associated with enlargement of individual fat cells and, under certain circumstances, as in childhood obesity or morbid obesity in adults, with increases in both cell number and cell size [1].

Hypercolorie diet intake has been associated with many diet-induced diseases including cardiovascular diseases, metabolic syndrome, and nonalcoholic fatty liver disease (NAFLD) [2]. Feeding a fat-rich and carbohydrate dietary components have been used to induce the signs and symptoms of human metabolic syndrome in rodents [3]. In the $21^{\text {st }}$ century, NAFLD has been described as the emerging clinical problem for the obese patients [4]. Active pathways in promoting this disease process in the liver both in humans and in mouse models are poorly described and are an active area of research.

Various animal models for obesity have been established to help better understanding the pathophysiology in metabolic diseases and to develop new therapies. In this study, we investigated the association of liver weight to body weight and pathophysiological changes in the liver tissues of fatty rat.

\section{METHODS}

Wistar rats of either sex obtained from the Central Animal House, BLDEU's Sri BM Patil Medical College Hospital and Research Center,
Vijayapur, India, were used in the study. They were housed individually in individually in polypropylene cages for 1 week of acclimation before the experiment is started. The study was reviewed and approved by the Institutional Animal Ethics Committee, BLDE University, Vijayapur. Rats were housed at $24 \pm 2^{\circ} \mathrm{C}$ temperature with relative humidity $(60 \pm 5 \%)$ and kept on a 12 hrs lightdark cycle. All animals had food and water ad libitum.

\section{Study design}

A total of 12 Wistar rats were used in this study. Rats weighing 170-220 g were assigned to Group 1 (control, $n=6$ ), remaining 6 rats were fed cafeteria diet to induce obesity (diet induced obesity) from the time of weaning and included in the study at the age of 19 weeks [5] then included in the study and assigned to Group 2 (study group, $n=6$ ). While control rats were maintained on standard chow, the study group was fed with the hypercalorie/cafeteria diet along with pellet chow.

\section{Hypercalorie/cafeteria diet [5,6]}

It consisted of three variants; (i) Condensed milk + bread + peanuts + pellet chow (4:1:4:1), (ii) cheese + boiled potatoes + pellet chow $(4: 2: 1)$, and (iii) chocolate + biscuits + dried coconut + pellet chow (3:2:4:1). These different variants were fed throughout the treatment period on alternate days.

\section{Parameters studied}

Animals in both groups were fasted for $24 \mathrm{hrs}$ and euthanized and subjected to gross necropsy. External features suggesting any abnormality were looked into. Liver organs from all the rats were collected. After gross necropsy examination, these livers were trimmed fat and blotted on filter paper and weighed [7].

These tissues were fixed in 10\% neutral buffered formalin overnight and subjected to routine standard histopathological processing. 
The study experiments were conducted as per the norms laid by Committee for the Purpose of Control and Supervision of Experimentation on Animals.

\section{Statistical analysis}

All the values will be expressed as the meanıstandard error mean and analyzed by unpaired Student's t. The level of statistical significance will be set at $\mathrm{p}<0.05$.

\section{RESULTS}

Liver weights (Table 1): Obese rats showed significantly higher liver weights than livers of normal control rats $(\mathrm{p}<0.05)$

No significant changes were observed in the liver tissues of normal (Group 1) control rats (Fig. 1).

The hematoxylin-and-eosin-stained sections showed an increase in the number of lipid droplets and sinusoidal congestion (Fig. 2) in the livers of obese rats (Group 2).

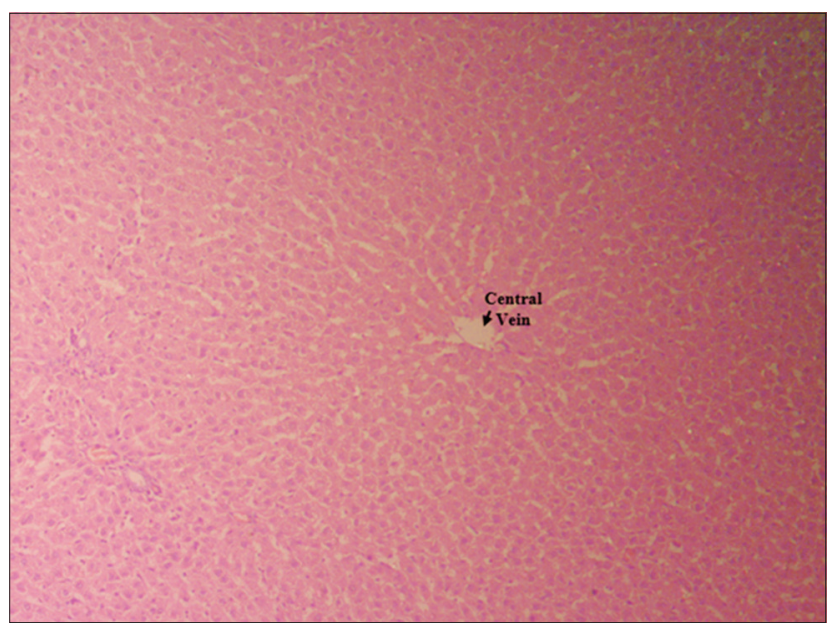

Fig. 1: Microscopic structure of liver tissue of control rats

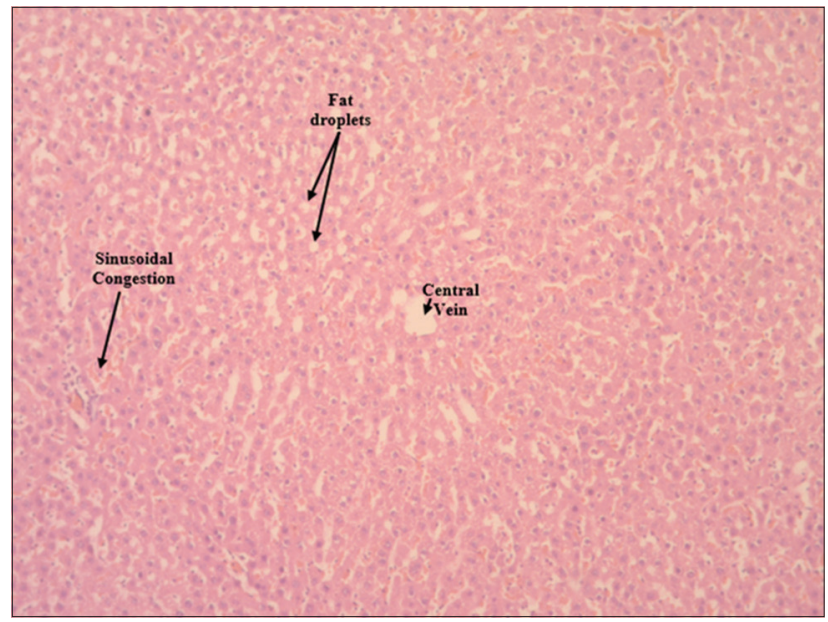

Fig. 2: Microscopic structure of liver tissue of obese rats

Table 1: Liver weight in control and obese groups

\begin{tabular}{lll}
\hline Group & Body weight $(g)$ & Liver weight (g) \\
\hline Control & $195.5 \pm 3.78$ & $7 \pm 0.37$ \\
Obese & $305 \pm 4.22^{*}$ & $9.3 \pm 0.42^{*}$ \\
\hline
\end{tabular}

${ }^{*} \mathrm{p}<0.05$ as per unpaired student's t-test

\section{DISCUSSION}

Increased liver weights observed in obese animals were due to hepatomegaly, which was confirmed by gross body weight exhibited by these animals. In a study where 19 WNIN obese mutant rats were used also seen similar observations [8]. Fatty liver disease is also called as NAFLD and is a common condition seen in all obese rodents arising genetically as well as experimentally induced $[9,10]$.

NAFLD is a multifactorial disease with a complex pathophysiology. The clinical markers of NAFLD are obesity, insulin resistance, and dyslipidemia [11]. Dysregulation of hepatic lipids, pro-inflammatory cytokines, and oxidative stress interact each other synergistically to promote hepatic fat accumulation over time [12]. Different dietary combinations and amounts have been used in various NAFLD induction studies [13-17]. Peroxisome proliferator-activated receptor $\gamma$ (PPAR $\gamma$ ) is a major transcription regulator particularly for liver lipogenesis [18]. The upregulation of hepatic PPAR $\gamma$ is commonly observed in hypercalorie diet fed mice [19]. In addition, the liver-specific deletion of PPAR $\gamma$ established the role of this factor as a prosteatotic factor in the development of NAFLD in mice [20]. Accordingly, inactivation of PPAR $\gamma$ promotes the free fatty acids efflux from the liver and muscle while increasing mass of the fat, which increases insulin sensitivity consequently [21].

Our previous studies have also shown that hypercalorie diet caused dyslipidemias and alterations in liver function tests associated with an increase in body weight of rats [22]. In this study, we also we detected increased weight of the liver tissues and histological features such as excessive accumulation of fat and sinusoidal congestion was observed in liver tissues of obese group of animals compared to liver tissues of control group of animals.

\section{CONCLUSION}

Hypercalorie diet is widely accepted model for the induction of obesity. We observed that use of hypercalorie/cafeteria diet resulted in an increase in liver weight, increased deposition of fat and sinusoidal congestion in the liver, which further leads to hepatocellular necrosis formation on the liver as the sinusoidal congestion is indicative of the presence of inflammation.

\section{REFERENCES}

1. Hirsch J, Batchelor B. Adipose tissue cellularity in human obesity. Clin Endocrinol Metab 1976;5(2):299-311.

2. Massiera F, Barbry P, Guesnet P, Joly A, Luquet S, Moreilhon-Brest C, et al. A Western-like fat diet is sufficient to induce a gradual enhancement in fat mass over generations. J Lipid Res 2010;51(8):2352-61.

3. Panchal SK, Brown L. Rodent models for metabolic syndrome research. J Biomed Biotechnol 2011;2011:351982.

4. Festi D, Colecchia A, Sacco T, Bondi M, Roda E, Marchesini G. Hepatic steatosis in obese patients: Clinical aspects and prognostic significance. Obes Rev 2004;5(1):27-42.

5. Kamalakkannan S, Rajendran R, Venkatesh RV, Clayton P, Akbarsha MA. Antiobesogenic and antiatherosclerotic properties of Caralluma fimbriata extract. J Nutr Metab 2010;2010:285301.

6. Harris RB. The impact of high - or low-fat cafeteria foods on nutrient intake and growth of rats consuming a diet containing 30\% energy as fat. Int J Obes Relat Metab Disord 1993;17(6):307-15.

7. Bratthauer GL. Avidinbiotin labeling of cellular antigens in cryostatsectioned tissue. In: Javois LC, editor. Methods in Molecular Biology. Vol. 4. Clifton JC: Humana Press; 1994. p. 175-84

8. Harishankar N, Kumar PU, Sesikeran B, Giridharan N. Obesity associated pathophysiological \& histological changes in WNIN obese mutant rats. Indian J Med Res 2011;134:330-40.

9. Bray GA, York DA. Genetically transmitted obesity in rodents. Physiol Rev 1971;51(3):598-646.

10. Bray GA. The Zucker-fatty rat: A review. Fed Proc 1977;36(2):148-53.

11. Smith BW, Adams LA. Nonalcoholic fatty liver disease and diabetes mellitus: Pathogenesis and treatment. Nat Rev Endocrinol 2011;7(8):456-65.

12. Johnson AM, Olefsky JM. The origins and drivers of insulin resistance. 
Cell 2013;152(4):673-84.

13. Chun MR, Lee YJ, Kim KH, Kim YW, Park SY, Lee KM, et al. Differential effects of high-carbohydrate and high-fat diet composition on muscle insulin resistance in rats. J Korean Med Sci 2010;25(7):1053-9.

14. Kohli R, Kirby M, Xanthakos SA, Softic S, Feldstein AE, Saxena V, et al. High-fructose, medium chain trans fat diet induces liver fibrosis and elevates plasma coenzyme Q9 in a novel murine model of obesity and nonalcoholic steatohepatitis. Hepatology 2010;52(3):934-44.

15. Murase T, Mizuno T, Omachi T, Onizawa K, Komine Y, Kondo H, et al. Dietary diacylglycerol suppresses high fat and high sucrose diet-induced body fat accumulation in C57BL/6J mice. J Lipid Res 2001;42(3):372-8.

16. Sato A, Kawano H, Notsu T, Ohta M, Nakakuki M, Mizuguchi K, et al. Antiobesity effect of eicosapentaenoic acid in high-fat/high-sucrose diet-induced obesity: Importance of hepatic lipogenesis. Diabetes 2010;59(10):2495-504.

17. Clarke SD. Polyunsaturated fatty acid regulation of gene transcription: A molecular mechanism to improve the metabolic syndrome. J Nutr 2001;131(4):1129-32.
18. Gavrilova O, Haluzik M, Matsusue K, Cutson JJ, Johnson L, Dietz KR, et al. Liver peroxisome proliferator-activated receptor gamma contributes to hepatic steatosis, triglyceride clearance, and regulation of body fat mass. J Biol Chem 2003;278(36):34268-76.

19. Vidal-Puig A, Jimenez-Liñan M, Lowell BB, Hamann A, Hu E, Spiegelman B, et al. Regulation of PPAR gamma gene expression by nutrition and obesity in rodents. J Clin Invest 1996;97(11):2553-61.

20. Morán-Salvador E, López-Parra M, García-Alonso V, Titos E, Martínez-Clemente M, González-Périz A, et al. Role for PPAR? In obesity-induced hepatic steatosis as determined by hepatocyte - And macrophage-specific conditional knockouts. FASEB J 2011;25(8):2538-50.

21. Yamauchi T, Kamon J, Waki H, Murakami K, Motojima K, Komeda K, et al. The mechanisms by which both heterozygous peroxisome proliferator-activated receptor gamma (PPARgamma) deficiency and PPARgamma agonist improve insulin resistance. J Biol Chem 2001;276(44):41245-54

22. Ambadasu B, Dange SV, Wali RS. Effect of caralluma fimbriata extract on appetite, body weight \& lipid profile in cafeteria diet-induced obesity in rats. Int J Pharm Pharm Sci 2013;5(4):536-9. 